\title{
ANTICANCER ACTIVITY OF B-SITOSTEROL FROM PLECTRANTHUS AMBOINICUS (LOUR. SPRENG.) LEAVES: IN VITRO AND IN SILICO STUDIES
}

\author{
POPPY ANJELISA Z HASIBUAN ${ }^{1 *}$, PANAL SITORUS ${ }^{2}$, DENNY SATRIA ${ }^{2}$
}

${ }^{1}$ Department of Pharmacology, Faculty of Pharmacy, University of Sumatera Utara, Medan, Indonesia. ${ }^{2}$ Department of Pharmaceutical Biology, Faculty of Pharmacy, University of Sumatera Utara, Medan, Indonesia. Email: poppyanjelisa@usu.ac.id

Received: 04 January 2016, Revised and Accepted: 27 February 2017

\section{ABSTRACT}

Objective: $\beta$-sitosterol is the steroid compound which is an important nutrient in the diet meal, hydrophobic and soluble in organic solvents and considered as a good biomarker due to its biological activity.

Methods: In vitro study was using 2,5-diphenyl tetrazolium bromide method towards T47D, MCF-7, HeLa, and WiDr cell lines. In silico docking using PLANTS program and visualized by Yasara program. The model of three dimension enzyme structures used in this research were epidermal growth factor receptor (EGFR), phosphatidylinositol-3-kinase (PI3K), estrogen receptor-alpha (ER- $\alpha$ ), ER-beta (ER- $\beta$ ), and human EGFR 2 (HER-2). Two and three dimensions of $\beta$-sitosetrol, ZSTK474, and tamoxifen as the standard were generated using Marvin Sketch program.

Results: $\beta$-sitosterol was found to have inhibitory concentration $50 \%$ of $0.55 ; 0.87 ; 0.76$, and 0.99 mM. $\beta$-sitosterol and ZSTK474 were inhibited EGFR and PI3K with docking score $-92.8195 ;-91.7920$ and $-91.7470 ;-94.7491 \beta$-sitosterol and tamoxifen were inhibited ER- $\alpha$, ER- $\beta$ and HER-2 with docking score $-78.5570 ;-89.535,-68.7717 ;-52.008$ and $-90.4908 ;-50.5576$, respectively.

Conclusion: Based on the results above that shows $\beta$-sitosterol provide effective as anticancer.

Keywords: $\beta$-sitosterol, Inhibitor, Anticancer, In vitro, In silico.

(C) 2017 The Authors. Published by Innovare Academic Sciences Pvt Ltd. This is an open access article under the CC BY license (http://creativecommons. org/licenses/by/4. 0/) DOI: http://dx.doi.org/10.22159/ajpcr.2017.v10i5.16931

\section{INTRODUCTION}

The diversity of medicinal plants in Indonesia is one of the chances in development potential of Indonesia in the globalization era [1]. The use of medicinal plant extracts for the treatment of human disease is an ancient practice and thus has greatly increased in recent years. Cancer is one of the most frequent and distressing diseases which increased during the past 50 years [2]. Research into plants with anticancer effects is still encouraged with a view to discover any new drugs with less toxic but more potent effects [3]. Indonesia has the potential diversity of plant species as medicinal plants.

One of these medicinal plants is Plectranthus amboinicus (Lour.) Spreng. The in vitro cytotoxic property of the crude extract of leaves was tested against HeLa, and showed that the n-hexane, ethylacetate and ethanol extracts had cytotoxic effect on HeLa cells with inhibitory concentration $50 \%\left(\mathrm{IC}_{50}\right.$ ) values $76.322 \mu \mathrm{g} / \mathrm{mL}, 143.291 \mu \mathrm{g} / \mathrm{mL}$, and $88.997 \mu \mathrm{g} / \mathrm{mL}$, respectively [4], and it showed cytotoxic effect on MCF7 cell lines, too [5]. The previous studies had shown that the n-hexane, ethylacetate extracts exhibited strong cytotoxic effect on T47D breast cancer cells with $\mathrm{IC}_{50}$ value of $44.716 \mu \mathrm{g} / \mathrm{mL}$ and $37.61 \mu \mathrm{g} / \mathrm{mL}$, respectively, and showed the synergistic effect in combination with doxorubicin to inhibit the HeLa cell line [4]. It showed the same effect in combination wtih doxorubicin to inhibit T47D cell line [5].

$\beta$-sitosterol is the phytosterol with chemical structure similar to the cholesterol. It is an important nutrient in the diet meal, hydrophobic and soluble in organic solvents and considered as a good biomarker due to its biological activity [6]. Broadly, $\beta$ - sitosterol is used as an antioxidant and an antidiabetic agent [7]. It is also considered to be highly effective in the treatment of prostate enlargement [8], to boost the function of $\mathrm{T}$ cells and primes the immune system to function and operate more efficiently [9]. Human liver microsome studies show that $\beta$ - sitosterol inhibits the cholesterol absorption [10]. It has shown the antifertility [11,12], anti-inflammatory and antipyretic activity [13]. The purposes of this research were to assess the activity of $\beta$ - sitosterol in inhibition the growth of T47D, MCF-7, HeLa and WiDr cell lines and the activity in inhibit of phosphatidylinositol-3-kinase (PI3K), EGFR, estrogen receptor-alpha (ER- $\alpha)$, estrogen receptor-beta (ER- $\beta$ ) and HER-2 with in silico method.

\section{METHODS}

Chemicals and reagents

n-hexane, ethylacetate and methanol were purchased from Merck (Darmstadt, Germany), dimethyl sulfoxide (Sigma-Aldrich, Germany), [3-(4,5-dimethylthiazol-2-yl)-2,5-diphenyl tetrazolium bromide] (MTT) (Sigma Chemical, St. Louis, MO), RPMI media and phosphate buffer saline foetal bovine serum (FBS) 10\% v/v (Gibco, Grand Island, NY, USA), silica gel 60H (Merck), thin-layer chromatography (TLC) silica gel $\mathrm{GF}_{254}$ (Merck).

\section{Extraction and isolation of $\boldsymbol{\beta}$-sitostero}

The P. amboinicus was obtained from Pematang Siantar, North Sumatera, Indonesia and was identified in Research Centre for Biology, Indonesian Institute of Science, Bogor, and the voucher specimen was deposited in herbarium. The leaves of $P$. amboinicus were dried at $45^{\circ} \mathrm{C}$ and ground into powder. The air-dried and powdered leaves of P. amboinicus. $(1 \mathrm{~kg})$ were repeatedly fractionated by cold maceration with $n$-hexane $(3 \times 3 \mathrm{~d}$, $7.5 \mathrm{~L}$ ). At room temperature and occasionally with stirring. The filtrate was collected and then evaporated under reduced pressure to give a viscous fraction and then freeze dried to dry [1,14-17]. n-hexane extract was fractionated with vacuum liquid chromatography using gradient eluent n-hexane: Ethylacetate $(100: 0 ; 90: 10 ; 80: 20 ; 70: 30 ; 60: 40$; $50: 50 ; 40: 60 ; 30: 70 ; 20: 80 ; 10: 90 ; 0: 100)$ and methanol (100) and silica gel $60 \mathrm{H}$ as stationary phase. All fractions were concentrated by rotary evaporator and were dried using freeze dryer to eliminate the existence of the remaining traces of water. Then, the fractions were analyzed by 
thin layer chromatography with silica gel $\mathrm{GF}_{254}$ as stationary phase and $\mathrm{n}$-hexane-ethylacetate as mobile phase. $\beta$-sitosterol was obtained using column chromatography and preparative TLC $[18,19]$.

\section{Cell lines and culture conditions}

HeLa, T47D, MCF-7, and WiDr cell lines were kindly provided by Parasitology Laboratory, Faculty of Medicine, University of Gadjah Mada, Indonesia. The cell lines were cultured in RPMI (Hela, T47D and WiDr) and DMEM (MCF-7) mediums, supplemented with 10\% (v/v) FBS, $2 \%$ penicillin-streptomycin and $0.5 \%$ fungizone in a $37^{\circ} \mathrm{C}$ incubator with $5 \% \mathrm{CO}_{2}{ }^{40}$.

\section{Cytotoxicity assay}

Cytotoxicity was determined by the MTT colorimetric assay. Briefly, T47D, MCF-7, HeLa and WiDr cell lines were plated at $10^{4}$ cells/well in a 96-well plate. Each well contained $1 \times 10^{4}$ cells. The culture cells were incubated in a humidified incubator at $37^{\circ} \mathrm{C}$ at atmosphere of $5 \% \mathrm{CO}_{2}$ and $95 \%$ air for $24 \mathrm{hrs}$. After incubation for $24 \mathrm{hrs}$ at $37^{\circ} \mathrm{C}$, the medium was discharged, and cells were treated by $\beta$-sitosetrol with different concentration and incubated for $24 \mathrm{hrs}$. MTT $0.5 \mathrm{mg} / \mathrm{mL}$ solution was added to each well and further incubated for $4 \mathrm{hrs}$ at $37^{\circ} \mathrm{C}$. Viable cells react with MTT to produce purple formazan crystals. After $4 \mathrm{hrs}$, the stopper 10\% SDS (Sigma Co. St. Louis) in $0.01 \mathrm{~N} \mathrm{HCl}$ (Merck) was added to dissolve the formazan crystal. The cells were then incubated for $24 \mathrm{hrs}$ in room temperature and protected from light. After incubation, the cells were shaken Optical density was read with an ELISA reader at $\lambda 595 \mathrm{~nm}$. The experimental data was absorbance of each well, and then converted to percentage of viable cells $[1,14,20]$.

Percentage of viable cell $=\frac{B-C}{A-C} \times 100 \%$

Where A, B and C are absorbance of control group, treatment group and medium (vehicle), respectively.

\section{In silico studies}

Aspire E1-470 series operated by Windows 7 Home Premium, Intel ${ }^{\circledR}$ Core $^{\mathrm{TM}}$ i3 -3217U (1,8 GHz, 3MB L3 cache), 32-bit, hard disc drive $500 \mathrm{~GB}$ and RAM memory 2 GB DDR3 L were used to run the molecular docking process.

In silico docking using PLANTS program and visualized by Yasara program. Co Pen Drive Linux KDE program was used to connecting
Windows operation system to Linux operation system. The model of three dimensions of enzyme structure used in this research was PI3K binding pocket with the protein data bank code 3DBS, IM17 for EGFR, 3PP0 for HER-2, 3ERT for ER- $\alpha$, and 1QKM for ER- $\beta$. They were obtained through from http://www.rscb.org/pdb. Two and three dimension conformation models of $\beta$-sitosterol, tamoxifen and ZSTK474 as the standard HER-2, ER- $\alpha$, ER- $\beta$ and PI3K inhibitor were generated by Marvin Sketch program [21,22].

\section{Statistical analysis}

All data were expressed as $\mathrm{IC}_{50}$ that analysis using probit in regression at SPSS 22.

\section{RESULTS AND DISCUSSION}

\section{Isolation and characterization of $\boldsymbol{\beta}$-sitosetrol}

The purity of $\beta$-sitosterol obtained was analyzed using TLC. The chromatogram gave positive results with Liebermann-Burchard reagent. Rf 0.50 indicated steroid group and confirmed with two-way TLC (mobile phase I: $n$-hexane:ethyl acetate 80:20 and mobile phase II: Toluene:ethyl acetate 90:10). Finally, elucidation of the structure of $\beta$-sitosterol with the data of UV spectrum (ethanol) at $\lambda$-max $268.5 \mathrm{~nm}$; infra-red (KBr) with wave number 3421.72; 2920.23; 2852.72; 1566.20; 1415.75 and $1111.00 \mathrm{~cm}^{-1}$. Carbon NMR spectrum ( $\left.75 \mathrm{MHz}, \mathrm{CDCl} 3\right)$ of pure isolates indicated by the chemical shift data A1 isolate 13C - NMR spectrum showed the presence of hydroxyl group $\delta \mathrm{C}=71.82 \mathrm{ppm}$ (C3) and two group ena $\delta \mathrm{C} 121.72$ (C6) and $\delta \mathrm{C} 140.76$ (C5). 1H-NMR spectrum $\left(300 \mathrm{MHz}, \mathrm{CDCl}_{3}\right.$ ) showed a multiplet $\delta \mathrm{H} 3.53-3.68 \mathrm{ppm}$ of the $\mathrm{H}-3$ and the characteristics of the $\mathrm{C}-3$ atom; singlet peak at $\delta \mathrm{H} 1,05 \mathrm{ppm}$ and $\delta \mathrm{H} 0.65 \mathrm{ppm}$; doublet at $\delta \mathrm{H} 0.95 \mathrm{ppm}$ and $0.93[7,8,19]$.

IC $_{50}$

MTT method was used to determine cell viability after incubation for $24 \mathrm{hrs}$. In every treatment, $\beta$-sitosetrol was shown to inhibit cells growth toward T47D, MCF-7, HeLa and WiDr cell lines. The IC $\mathrm{I}_{50}$ value of $\beta$-sitosetrol was $0.55 ; 0.87 ; 0.76$, and $0.99 \mathrm{mM}$, respectively.

\section{Molecular docking}

The root mean square deviation (RMSD) values resulted from these ligand docking were $1,5761 \AA \AA$ for 3DBS; $1,6970 \AA$ for $1 \mathrm{M} 17 ; 1.4270 \AA$ for 3ERT; $0.3900 \AA$ for $1 \mathrm{QKM}$ and $1.1930 \AA$ for 3PP0. The RMSD was obtained $<2.0000 \AA$ indicating that the docking methods were valid [23]. In silico docking between $\beta$-sitosetrol into the 3DBS, 1M17,

Table 1: Docking score between ligand and protein target

\begin{tabular}{lllllll}
\hline S. No & Ligand name & \multicolumn{2}{l}{ Docking score } & & & \\
\cline { 3 - 7 } & & PI3K & EGFR & HER-2 & ER- $\boldsymbol{\alpha}$ & ER- $\boldsymbol{\beta}$ \\
\hline 1 & ZSTK474 & -94.7491 & -91.7920 & & -59.5350 & - \\
2 & Tamoxifen & & & -52.0080 \\
3 & $\beta$-sitosterol & -91.7470 & -92.8195 & -90.4908 & -78.5570 & -68.7717 \\
\hline
\end{tabular}

EGFR: Estimated glomerular filtration rate, HER: Hyperemesis education and research, ER- $\alpha$ : Estrogen receptor- $\alpha$, ER- $\beta$ : Estrogen receptor- $\beta$

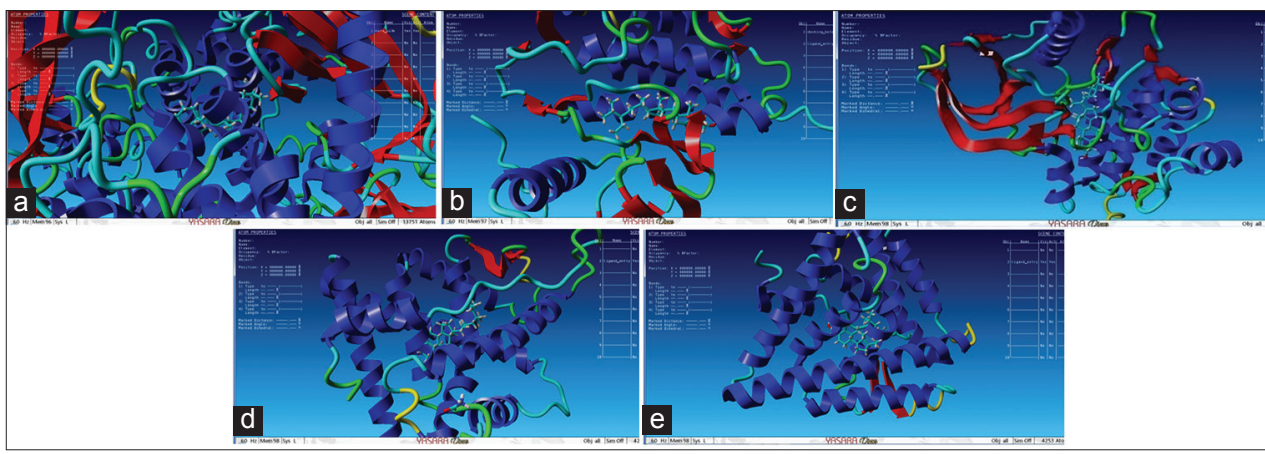

Fig. 1: Visualization of interaction between, (a) $\beta$-sitosterol with phosphatidylinositol-3-kinase, (b) $\beta$-sitosterol with epidermal growth factor receptor, (c) $\beta$-sitosterol with HER-2, (d) $\beta$-sitosterol with estrogen receptor-alpha, (e) $\beta$-sitosterol with estrogen receptor-beta 
3ERT, 1QKM and 3PP0 binding pocket result in the docking score in Table 1 is showed the results of docking score. Fig. 1 is showed the results of visualization of $\beta$-sitosterol to PI3K, EGFR, ER- $\alpha$, ER- $\beta$ and HER-2 using Yasara.

The docking score represents the binding affinity of the ligand to the target protein. The docking of PI3K, EGFR, ER- $\alpha$, ER- $\beta$ dan HER-2 target with compounds using docking procedure revealed that all the computationally predicted lowest energy complexes of PI3K, EGFR, ER- $\alpha$, ER- $\beta$ dan HER-2 are stabilized by intermolecular hydrogen bonds and stacking interactions [21]. Docking score of $\beta$-sitosterol was lower than ZSTK474 as kinase inhibitor especially PI3K but higher in inhibition of EGFR. Docking score of $\beta$-sitosterol was lower than tamoxifen as ER- $\alpha$ inhibitor but higher in inhibition of ER- $\beta$ and HER-2. In silico drug design can play a significant role in all of the stages of drug development from preclinical assessment to the end of clinical development [24]. The results were obtained at in silico screening have shown that it represents the best step (way) to get an accurate result in a short time and saving manner [25].

PI3K pathway plays important roles in tumor initiation and progression, including those in proliferative activity and in apoptosis. PI3K signaling is also commonly associated with the metastatic cascade in carcinoma. Although several aspects of tumor inhibition are not fully understood, numerous small molecule inhibitors targeting the PI3K pathway is currently being studied in clinical trials [26]. There are strong relationship between EGFR, PI3K, PI3K/AKT/mTOR and ER- $\alpha$, ER- $\beta$ and HER-2 signaling is frequently deregulated due to mutations affecting one of its upstream regulators the EGFR receptor and other components within the pathway [27-29].

\section{CONCLUSION}

$\beta$-sitosterol is steroid from P. amboinicus (Lour.) Spreng. It was showed to have the activity in inhibition of cancer growth toward T47D, MCF-7, HeLa and WiDr cell lines and through PI3K, EGFR, ER- $\alpha$, ER- $\beta$ dan HER-2 pathways and they are potential to develop as anticancer.

\section{ACKNOWLEDGMENT}

We gratefully thank DP2M DIKTI (Directorate of Higher Education) Ministry of Research Technology and High Education, Indonesia through "Hibah Bersaing" Research Grant 2016 for financial support in the study.

\section{REFERENCES}

1. Satria D, Furqan M, Hadisahputra S, Rosidah. Combinational effects of ethylacetate extract of Picria fel-terrae lour and doxorubicin on T47d breast cancer cells. Int J Pharm Pharm Sci 2015;7(7):73.

2. Jemal A, Siegel R, Xu J, Ward E. Cancer statistics, 2010. CA Cancer J Clin 2010;60(5):277-300.

3. Siegel RL, Miller KD, Jemal A. Cancer statistics, 2015. CA Cancer J Clin 2015;65:5-29.

4. Hasibuan PA, Rosidah. Combination effect of ethylacetate extract of Plectranthus amboinicus (Lour.) Spreng. with doxorubicin against HeLa cell lines. Int J Pharm Clin Res 2016;8(5):357-60.

5. Hasibuan PA, Chrestella J, Satria, D. Combination effect of ethylacetate extracts of Plectranthus amboinicus (Lour). Spreng. with doxorubicin against T47D breast cancer cells. Int J Pharm Pharm Sci 2015;7(10):156-9

6. Jirge S, Tatke P, Gabhe SY. Marker based standardization of commerical formulations and extracts containing beta-sitosterol D-glucoside using HPTLC. Int J Res Ayurveda Pharm 2010;1(2):616-23.

7. Karan SK, Mishra SK, Pal DK, Mondal A. Isolation of $\beta$ - sitosterol and evaluation of antidiabetic activity of Aristolochia indica in alloxan induced diabetic mice with reference to in-vitro antioxidant activity.
J Med Plant Res 2012;6(7):1219-23.

8. Dufoour B. The effectiveness of beta-sitosterol from an extract of African pygeum, on the functional symptoms of prostatic adenoma. J Ann Urol 1984;18:193-5.

9. Bouic PJ, Etsebeth S, Liebenberg RW, Albrecht CF, Pegel K, Van Jaarsveld PP. Beta-sitosterol and beta-sitosterol glucoside stimulate human peripheral blood lymphocyte proliferation: Implications for their use as an immunomodulatory vitamin combination. Int $\mathrm{J}$ Immunopharmacol 1996;18(12):693-700

10. Shefer S, Salen G, Nguyen L, Batta AK, Packin V, Tint GS, et al. Competetive inhibition of bile acid synthesis by endogenous cholestanol and sitosterol in sitosterolemia with xanthomatosis. J Clin Invest 1988;82:1833-9.

11. Malini T, Vanithakumari G. Antifertility effects of beta-sitosterol in male albino rats. J Ethnopharmacol 1991;35:149-53.

12. Nema RK, Yuvraj G, Ramanathan L, Sripriya S, Deecaraman M, Kishore L, et al. Effect of $\beta$ - sitosterol fraction of Ocimum gratissimum on reproductive parameters of male rats. Asian J Biochem Pharm Res 2011;3(1):591-7.

13. Gupta MB, Nath R, Srivastava N, Shanker K, Kishor K, Bhargava KP. Anti-inflammatory and antipyretic activities of betasitosterol. Planta Med 1980;39(2):157-63.

14. Anggraeni R, Hadisahputra S, Silalahi J, Satria D. Combinational effects of ethylacetate extract of Zanthoxylum acanthopodium DC. with doxorubicin on T47D breast cancer cells. Int J Pharmtech Res 2014;6(7):20-33

15. Sitorus P, Satria D. Antibacterial activity of ethanol extractand volatile oil of laja gowah rhizome (Alpinia malaccensis Burm. F Roscoe.) against Staphylococcus aureus and Escherichia coli. Asian J Pharm Clin Res 2016;9(2):342-4.

16. Dalimunthe A, Achmad S, Satria D. Phenolic, flavonoid content and antioxidant activities of ethylacetate extract of Litsea cubeba (Lour.) Pers. Barks. Pharm Chem 2016;8(19):466-8.

17. Sihotang Y, Silalahi J, Hadisahputra S, Anjelisa P, Satria D. Cardioprotective effect of ethylacetate extract of poguntano (Picria felterrae Lour.) against doxorubicin-induced cardiotoxicity in rats. Int $\mathrm{J}$ Pharm Clin Res 2016;8(5):466-70.

18. Satria D, Nasution NP, Ilyas S. Cytotoxcicity effect of sea horse (Hippocampus trimaculatus Leach.) extract and fractions on MCF-7 cell line. Int J Pharmtech Res 2014;6(1):212.

19. Sitorus P, Harahap U, Pandapotan M, Barus T. Isolation of $\beta$-sitosterol from n-hexane Extract of Picria fel-terrae Lour. leave and study of its antidiabetic effect in alloxan induced diabetic mice. Int $\mathrm{J}$ pharmtech Res 2014;6(1):137-41.

20. Hasibuan PA, Harahap U, Sitorus P, Satria D. Ethylacetate extract of Zanthoxylum acanthopodium DC. Fruit against doxorubicin-resistanced T47D cells. Pharm Chem 2016;8(20):172-4.

21. Purnomo H, Jenie UA, Nugroho AE, Pranowo HD. In silico and in vivo qualitative relationships of para-aminophenol analogues. Int J Pharm Clin Res 2016;8(5):367-71.

22. Hasibuan PA, Satria D, Harahap U, Silalahi J. In silico analysis of picfeltarraenin IA and IB as potential PI3K and EGFR inhibitor. Pharm Chem 2016;8(19):666-70.

23. Terstappen GC, Reggiani A. In silico research in drug discovery. Trends Pharmacol Sci 2001;22:23-6

24. Bharath EN, Manjula SN, Vijaychand A. In silico drug design tool for overcoming the innovation deficit in the drug discovery process. Int $\mathrm{J}$ Pharm Pharm Sci 2011;3(2):8-12.

25. Verbanac D, Jelic D, Stephanic V, Tatic I. Combined in silico and in vitro approach to drug screening. Croat Chem Acta 2005;78(2):133-9.

26. Lu Y, Muller M, Smith D, Dutta B, Komurov K, Iadevaia S, et al. Kinome siRNA-phosphoproteomic screen identifies networks regulating AKT signaling. Oncogene 2011;30(45):4567-77.

27. Hennessy BT, Smith DL, Ram PT. Exploiting the PI3K/AKT pathway for cancer drug discovery. Nat Rev Drug Discov 2005;4:988-1004.

28. Joshi A, Manoj G, Urmila JJ. Identification of potential novel EGFR inhibitors using a combination of pharmacophore and docking methods. Int J Pharm Pharm Sci 2015;7(6):77-91.

29. Holla SN, Venna N, Bairy KL, Amruta T, Shreedhar HN. HER-2 gene, receptors and drug target: A systematic review. Int J Pharm Pharm Sci 2016;8(4):4-9. 